\title{
MONITORING AND OBSERVATORIES
}
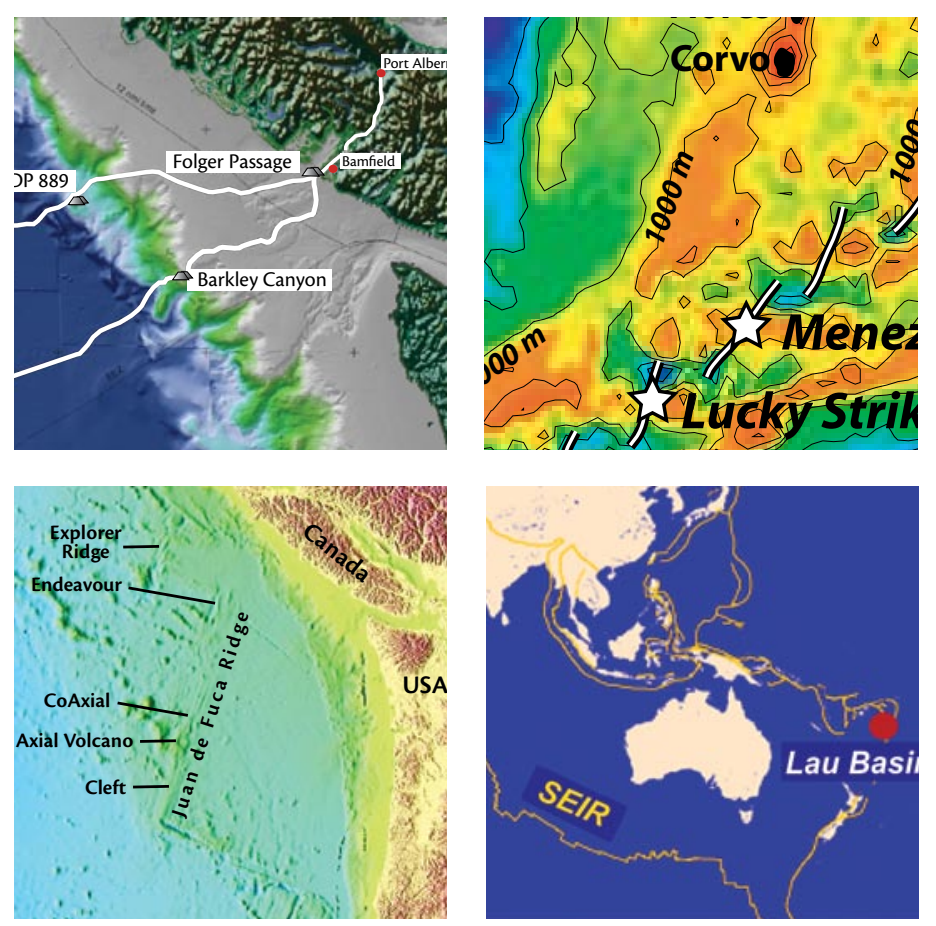

Multidisciplinary, Time-Series Observations at Mid-Ocean Ridges br s. kim Juniper,

JAVIER ESCARTIN, AND MATHILDE CANNAT 
Mid-ocean ridges represent one of the few environments where it is possible to directly and regularly observe the connectivity among tectonic, volcanic, geochemical, and biological processes. This interaction of life and earth processes related to crustal accretion has provided a focus for a great deal of interdisciplinary research since the discovery of seafloor hydrothermalism in 1977 (Lonsdale, 1977). Exploration and comparison of spreading ridges and hydrothermal systems in different areas of the world continue to advance understanding of cause-and-effect relationships.

Many critical features of these rapidly evolving systems can only be discovered and understood through time-series observations. These observations can take the form of repeat visits, continuous offline monitoring by autonomous instruments, or continuous online monitoring by instruments with satellite or cable links to shore. The first such studies were return visits during the 1980 s to vent fields at $13^{\circ} \mathrm{N}$ on the East Pacific Rise and in the Galápagos Spreading Center. Comparison of known sites between visits revealed that the activity of individual vents and entire vent fields can vary substantially at a scale of years, and that these fluctuations can strongly affect the abundance and distribution of specialized vent fauna (Fustec et al., 1987; Hessler et al., 1988). During the 1990s, civilian access to the SOSUS acoustic listening network in the Northeast Pacific provided researchers with the means for remotely detecting seafloor eruptions on the Juan de Fuca and Gorda Ridges. Event-response studies at eruption sites in this region (Embley et al., 1999), together with the serendipitous discovery and follow-up investigation of a seafloor eruption at $9^{\circ} \mathrm{N}$ on the East Pacific Rise (Haymon et al., 1993; Shank et al., 1998), greatly increased our appreciation of the hydrothermal and biological consequences of magma injection and eruption events. These same studies documented the impressive capacity of microorganisms (Juniper et al., 1995; Huber et al., 2003) and vent fauna (Tunnicliffe et al., 1997) to quickly colonize and exploit new sources of venting, and reinvigorated research into the propagation of vent species along mid-ocean ridges.

A number of studies have deployed autonomous monitoring instruments at vents and around mid-ocean ridges to investigate geophysical and hydrothermal processes. However, coordinated, multidisciplinary instrument deployments have so far been rare, limiting our ability to observe process connectivity. Johnson et al. (2000) provide a glimpse of the potential power of coordinated, multidisciplinary monitoring. They describe the capture of both earthquake events and the subsequent impact on hydrothermal and biological processes by instruments deployed independently for separate studies on the Endeavour Segment of the Juan de Fuca Ridge.

In this article we examine some of the outstanding scientific questions at midocean ridges that require coordinated, multidisciplinary, time-series observations. We also review the various experimental approaches being developed to accomplish such observations, from the coordination of instrument deployments through to the construction of cabled seafloor observatories. 


\section{OUTSTANDING PROBLEMS}

How much heat and mass do midocean ridges contribute to the ocean and atmosphere?

Mid-ocean ridges are major zones of heat and matter exchange between Earth's interior and the ocean and atmosphere. These exchanges take place in the form of magmatism and hydrothermalism. The estimated yearly volume of emplaced magma is about $18 \mathrm{~km}^{3}$ (Bird, 2003); its extrusive portion $\left(\sim 3 \mathrm{~km}^{3}\right)$ is roughly three times the volume of that erupted annually by subaerial volcanoes. The estimated yearly flux of hydrothermal fluids is of the order of $10^{14}-10^{16} \mathrm{~kg}^{3}$ (Stein and Stein, 1994), comparable in magnitude to the fluid discharge of any one of Earth's major rivers (Dai and Trenberth, 2002).

Hydrothermal circulation in nearridge regions carries an estimated onefifth of Earth's total heat flux (Stein and Stein, 1994), and it also conditions the temperature distribution in the newly formed oceanic plates, with critical consequences to their rheology, faulting, and magmatic processes. Despite their major contribution to the thermal balance of our planet, we still do not know the dimensions of mid-ocean ridge hydrothermal cells and how deeply they can

S. KIM JUNIPER (kjuniper@uvic.ca) is Professor, School of Earth and Ocean Sciences and Department of Biology, University of Victoria, British Columbia, Canada. JAVIER ESCARTIN is CNRS Research Scientist, Marine Geosciences Team, Institut de Physique du Globe, Paris, France. MATHILDE CANNAT is CNRS Research Scientist, Marine Geosciences Team, Institut de Physique du Globe, Paris, France extract heat from newly formed, oceanic plates. We know little of how hydrothermal cells vary in time and space. We also do not know what proportion of the total near-ridge heat flux is carried by spectacular high-temperature, blacksmoker-type fluids, and what proportion by lower-temperature, diffuse discharges that support most of the vent biomass. These very basic gaps in knowledge limit our understanding of planetary heat transfer.

A similar lack of basic information limits our ability to quantify the contribution of mid-ocean ridges to global chemical fluxes. Hydrothermal discharge is the primary vector for mass transfer from the oceanic lithosphere to the overlying ocean. The composition of hydrothermal fluids depends on physical and chemical factors, such as the temperature and depth of water-rock interactions, the nature of the rock medium, the fluid temperatures at the vents, and the dynamics of hydrothermal upflow (see Tivey, this issue). Hydrothermal fluids that have reacted with ultramafic (i.e., mantle-derived) rocks are, for example, greatly enriched in hydrogen and methane (Charlou et al., 2002) compared to fluids that have reacted with basaltic (i.e., magmatic) rocks. We do not know what proportion of near-ridge hydrothermal fluids have interacted with the two types of rocks. Hydrothermal fluids may also precipitate a portion of the leached chemical compounds at depth in the crust instead of transferring them to the ocean's water column. This transfer is expected to occur if relatively weak fluid convection allows for fluid temperatures to decrease below the reaction threshold temperatures for precipitating mineral species. Hydrothermal fluids will also precipitate chemical compounds near the seafloor in the hydrothermal stockwork and chimney system, and lose others to support the variety of life forms at vent ecosystems (see Fisher et al., this volume). All of these processes, as well as biological processes, and their variability in time and space, must therefore be quantified in order to constrain the hydrothermal chemical output to the global ocean. This quantification will not be possible without the coordinated effort of many disciplines and the pooling of observational resources at mid-ocean ridge observatories.

How can hydrothermal circulation influence faulting and magmatic processes?

At mid-ocean ridges, vigorous axial hydrothermal circulation to significant depth appears to produce the very narrow axial magma mush zone inferred from seismic data for the fast-spreading East Pacific Rise (Dunn et al., 2000). Such vigorous hydrothermal circulation requires substantial permeabilities of the rock medium that are best achieved in fractured rock formations. Hydrothermal circulation and the tectonic activity related to plate divergence are therefore expected to be closely linked. The permeability distribution in nearridge regions is also expected to vary over short temporal and spatial scales due to chemical precipitation, or to the emplacement of new, unfractured lava. Understanding this interplay among magmatic, tectonic, and hydrothermal processes is key to understanding how seafloor spreading works. Because each of these processes is inherently variable 
in time and space, and each is expected to influence the others, only coordinated, continuous observations by several disciplines can resolve their interactions.

\section{How do chemosynthetic}

ecosystems respond

to geological forcing?

Environmental instability is one characteristic of hydrothermal vent habitats that is likely common to the entire global mid-ocean ridge system. Oxidation of reducing substances in hydrothermal fluids by chemolithautotrophic microorganisms supports biological productivity at vents. Variability in fluid discharge and fluid chemistry will therefore impact the growth of vent microbes and their animal consumers. This same source of environmental variability will also influence the distribution of species in vent habitats because many live at or near their physiological limits. Fluid physico-chemical conditions experienced by vent organisms fluctuate at time scales of seconds to years as a result of turbulent mixing, tidal cycles, mineralization of subsurface conduits, and cooling of heat sources, as well as being subjected to catastrophic changes caused by local cracking of sulfide and rock substrata, and seismic and volcanic events. The bare-rock and mineral substrata colonized by vent organisms are also a source of instability. Seafloor volcanic eruptions can wipe out entire communities of vent organisms and reset the ecological clock to an early successional stage (Shank et al., 1998). On sulfide chimneys and larger edifices, new substratum is constantly being added by mineral accretion while structural collapse locally disturbs habitat.
Understanding the ecological impact of these various sources of geological forcing requires time-series observations and, perhaps, in situ experimentation. Laboratory studies of individual vent faunal species can identify physiological processes and establish limits but cannot be used to predict how entire communities will react and interact as their habitat changes. Our understanding of the relationship of faunal colonization and succession processes to natural disturbances should see significant advances with the continuous observation possibilities offered by observatory technologies. Several studies have concluded that faunal composition shifts provoked by perturbations can occur at scales of weeks to months. Yet, repeat visits by submersible are usually annual, at best.

In addition to the ecological questions that are specific to the mid-ocean ridge environment, hydrothermal vent ecol- cesses as a result of the coupling of vent ecosystems to geothermal rather than solar energy, and to geological rather than seasonal or climatic cycles. Observatory technologies will greatly enhance the experimental power of these test benches, overcoming many of the limitations inherent in the remote locations of mid-ocean ridges.

\section{PRESENT AND FUTURE OBSERVATORIES AT MID- OCEAN RIDGES}

National and international groups and programs are presently installing or planning five mid-ocean ridge observatory projects at locations that represent a range of spreading rates and tectonic settings (Figure 1). In 2008, NEPTUNE Canada will deploy the first stage of the NEPTUNE (North-east Pacific Timeseries Undersea Network Experiments) cabled observatory on the Endeavour

\section{...solid earth and ocean processes are linked, and those links cannot be understood without a coordinated effort by scientists representing many disciplines and countries.}

ogy is approaching a point where we can begin using these unique ecosystems as a test bench for elements of ecological theory, the entire body of which has been developed elsewhere. Ecological ideas and concepts can be put on trial in a setting where there are some different basic rules governing life and ecosystem pro-
Segment of the medium-spreading-rate Juan de Fuca Ridge. A European project is underway to establish an observatory on the slow-spreading Mid-Atlantic Ridge, in the so-called MOMAR (Monitoring the Mid-Atlantic Ridge) area. The Ridge 2000 program in the United States has identified three Integrated Study 
Sites (ISS) for intensive, interdisciplinary investigations that will combine continuous observation with surveys and repeat visits. The ISS include the fast-spreading East Pacific Rise at $9^{\circ} \mathrm{N}$, the Lau back-arc basin in the western Pacific, and the Juan de Fuca Ridge Endeavour Segment.

\section{Slow-Spreading Ridges}

Slow-spreading mid-ocean ridges display large variability in magma supply, tectonic structure, lithospheric composition, and overall depth of axis. The wide range of hydrothermal systems discovered to date is a consequence of this variability: they can be hosted by peridotites or basaltic rocks (Bougault et al., 1993), and they occur at depths ranging from less than $1000 \mathrm{~m}$ to greater than $3000 \mathrm{~m}$ below the sea surface. They can be located at the center of a ridge segment or near its end where the ridge intersects a transform fault, and they can occur within the rift valley or along the flanking, topographically high fault blocks.

In 1998, the InterRidge scientific community selected the Mid-Atlantic Ridge south of the Azores to be the site of the MOMAR program (Figure 2). This area has been studied since the FrenchAmerican Mid-Ocean Undersea Study (FAMOUS) in the 1970s (e.g., Heirtzler and Le Pichon, 1974). MOMAR planners seek to implement long-term observations to improve understanding of interactions and feedbacks among hydrothermal, tectonic, magmatic, and biological processes. Five main vent sites, representing the range of variability, have been discovered in the area: Lucky Strike, Rainbow, Menez Gwenn, Saldanha, and Menez Hom (see Figure 2).

To capture the variability in hydrothermalism along one ridge segment, long-term observatories will first be deployed at the Lucky Strike site, and subsequently at the Rainbow site. Lucky Strike is located at the summit of a central volcano at 1700-m depth, and is underlain by a recently discovered axial magma chamber at mid-crustal level (Singh et al., 2006). This site shows sustained levels of microseismicity, and a possible magmatic event in 2001 (Dziak et al., 2004). It is one of the largest sites found along the Mid-Atlantic Ridge, with numerous active and inactive vents

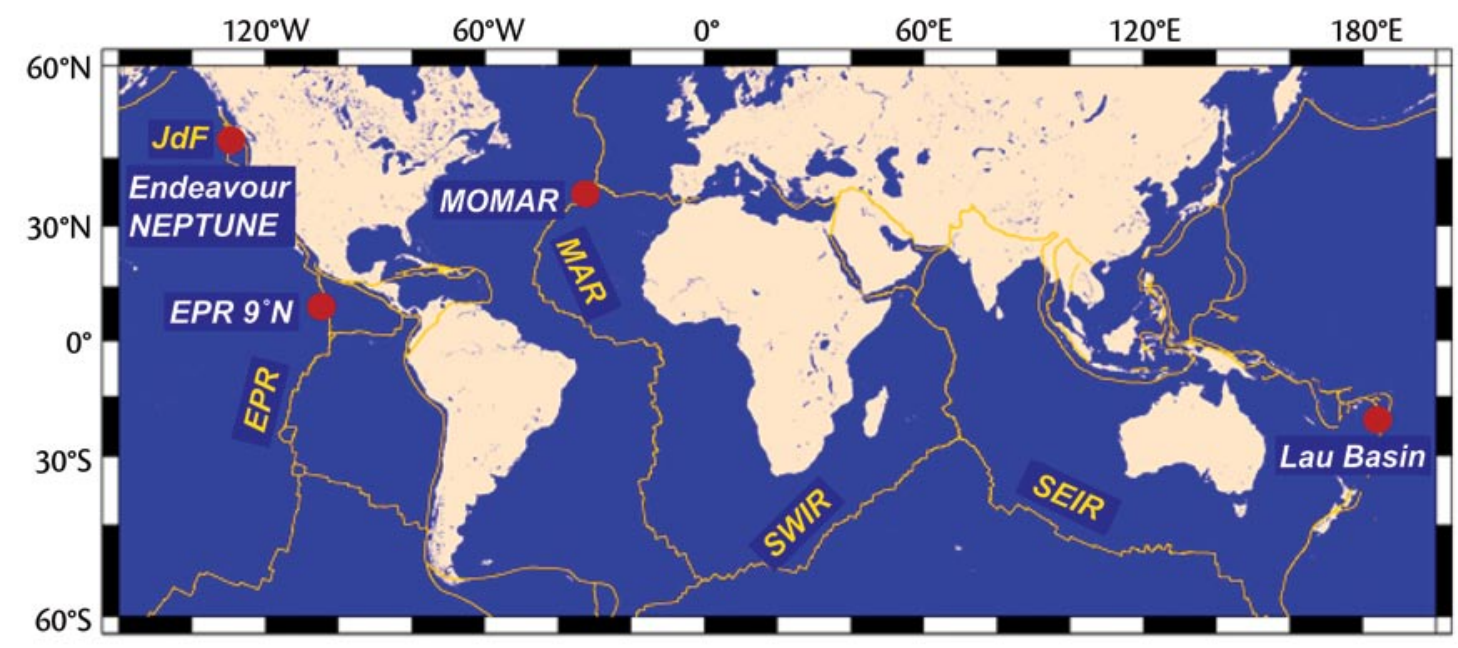

Figure 1. Location of presently proposed monitoring programs along the global mid-ocean ridge system. The NEPTUNE cabled observatory will be deployed on the Endeavour Segment of the Juan de Fuca Ridge (JdF). The MOMAR (Monitoring the Mid-Atlantic Ridge) area is located on the Mid-Atlantic Ridge (MAR) south of the Azores. Three Ridge 2000 Integrated Study Sites (ISS) are being developed on the East Pacific Rise (EPR) near $9^{\circ} \mathrm{N}$, in the Lau back-arc basin, and on the Juan de Fuca Ridge Endeavour Segment. No monitoring efforts are currently planned for the Southwest Indian Ridge (SWIR) or the Southeast Indian Ridge (SEIR). 
and zones of diffuse flow extending over $\sim 1 \mathrm{~km}^{2}$. The Rainbow site, at a depth of $2300 \mathrm{~m}$, is located at the offset between two segments of the ridge axis (Gràcia et al., 2000). The hydrothermal fluids are charged in methane, hydrogen, $\mathrm{Cu}, \mathrm{Ni}$, $\mathrm{Zn}$, and Co, reflecting the interaction between the water heated by a magmatic source and the peridotites hosting the system (e.g., Holm and Charlou 2001; Charlou et al., 2002).

The first phase of in situ monitoring, initiated in 2006 and continuing in 2007-2008, involves autonomous instrumentation installed primarily at the Lucky Strike site. The program is backed by a European Union-funded research network (MOMARNet) and a technology development program (EXOCET/D) together with European Union national research programs. The first time series monitors temperature, seismicity, seafloor elevation, pressure, and biological processes, and it will be complemented in the future with additional chemical, physical, and biological parameters. At medium term ( $\sim 3-5$ years $)$, a second phase will bring real-time monitoring, with data transmission from seafloor instrumentation to a buoy communicating with land via satellite. Integrated Ocean Drilling Program (IODP) drilling with in situ monitoring of hydrology and biology in the drillholes is also planned at the Rainbow site. This second phase of MOMAR monitoring will be developed within the European Union network of circum-European deep-sea observatories
(ESONET), which will establish its first test sites in 2008-2009. Full implementation of the MOMAR project includes the possibility of a cable connection to shore, and is expected for 2012.

\section{Medium-Spreading Ridges}

The Juan de Fuca Ridge, an intermediate-rate spreading ridge in the Northeast Pacific Ocean (Figure 3), has been intensely studied for more than 20 years. Time-series submersible observations (Sarrazin et al., 1997; Embley et al., 1999), hydrothermal plume surveys (Baker et al., 1995b), and hydro-acoustic earthquake monitoring by the SOSUS array (Fox et al., 1995) have shown that the Juan de Fuca Ridge is punctuated by dynamic events such as dike injec-

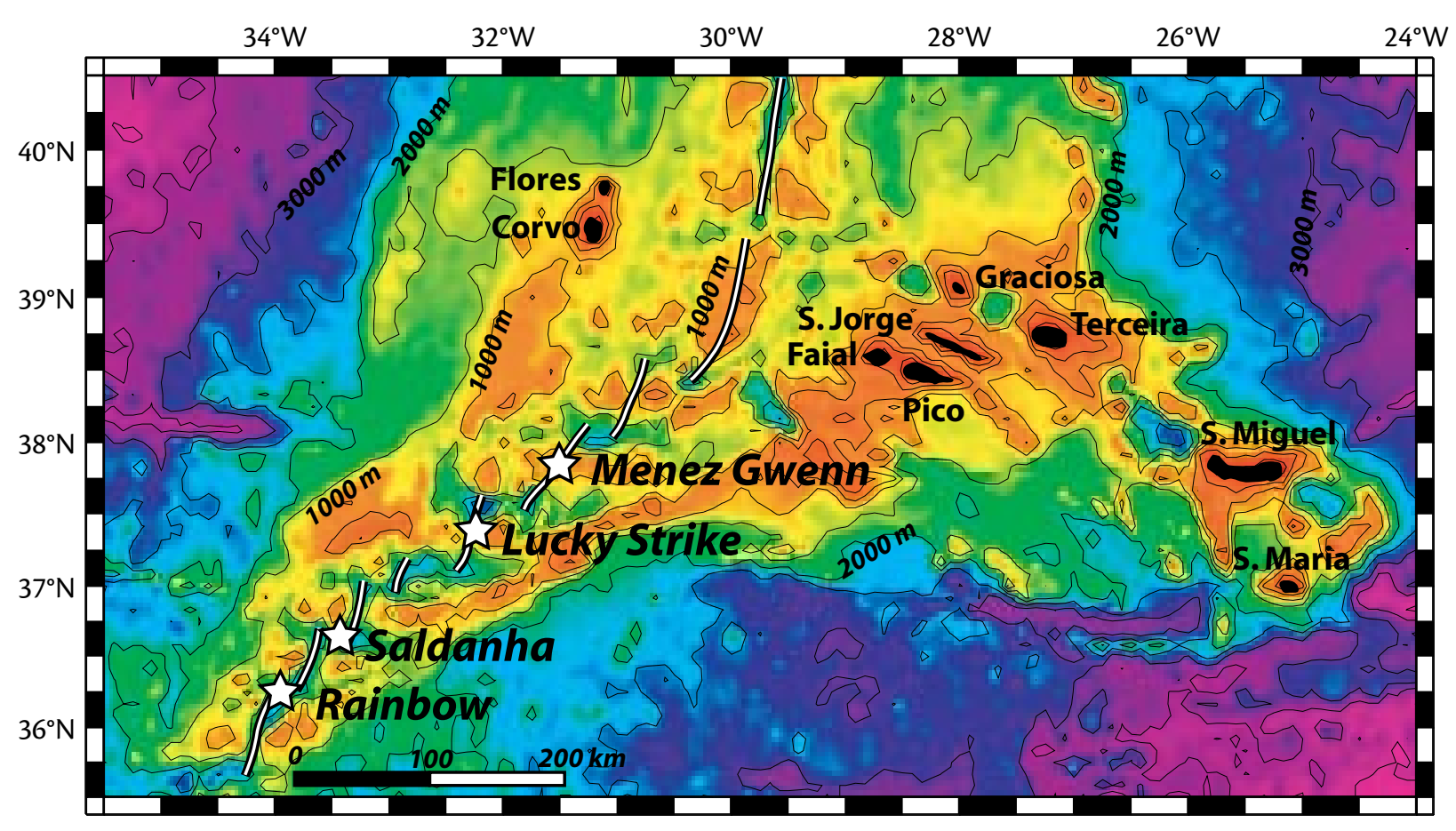

Figure 2. Simplified bathymetric map of the MOMAR area on the Mid-Atlantic Ridge near the Azores, showing locations of hydrothermal vent sites that have been discovered so far in this region. The Menez Hom site (not shown) is located near Lucky Strike. 


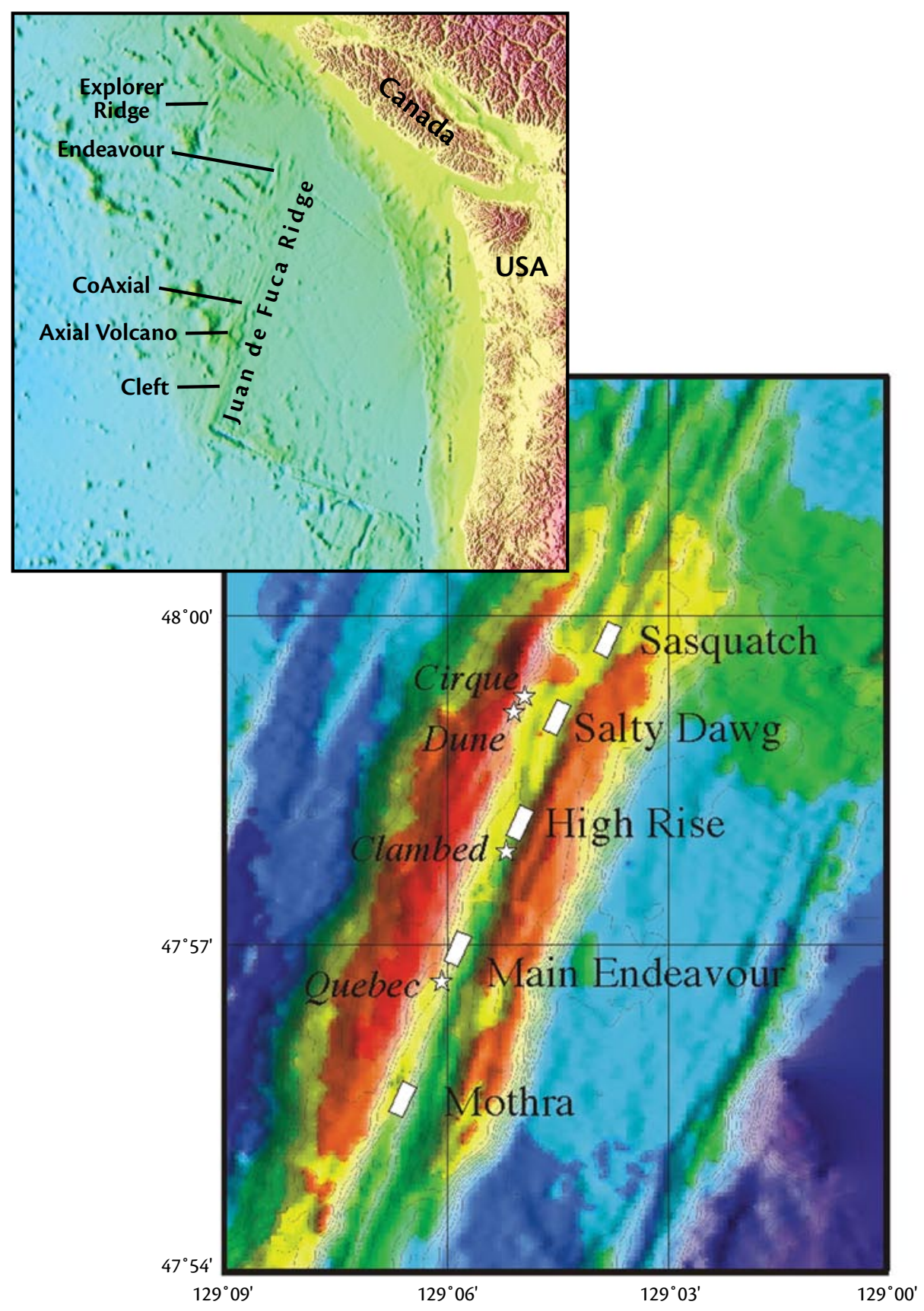

Figure 3. The five known hydrothermal vent fields (rectangles) of the Endeavour Segment of the Juan de Fuca Ridge. Stars indicate significant active hydrothermal sites outside of the vent fields outlined by the rectangles. Insert shows location of Endeavour Segment in relation to other segments of the Juan de Fuca Ridge and other spreading ridges in the Northeast Pacific Ocean. Lower right figure after Kristall et al. (2006) tions and tectonic earthquakes followed by a general return to quiescence. This episodic activity contrasts with the dynamic of fast-spreading ridges, where thermal and mass fluxes are larger and more continuous, and slow-spreading ridges, where thermal and eruptive events are infrequent and isolated. The large body of published research on the Juan de Fuca Ridge provides a basis for examining linkages among geological, biological, and hydrothermal processes within the context of an intermediate spreading-ridge environment. Individual segments of the Juan de Fuca Ridge are at different stages of magmatic and tectonic evolution, resulting in differences in the observed hydrothermal activity. Researchers have focused on three areas: the Endeavour segment, Axial Seamount, and the northern part of the Cleft Segment. The Endeavour Segment is highly active tectonically and hydrothermally while Cleft and Axial are sites of high magmatic flux with less hydrothermal venting.

\section{NEPTUNE Canada}

\section{In 2007-2008, NEPTUNE Canada} will deploy Stage 1 of the NEPTUNE regional cabled observatory (RCO) in the Northeast Pacific Ocean. An $800-\mathrm{km}$, powered, fiber-optic cable will loop out from a shore station at Port Alberni, Vancouver Island, to the Juan de Fuca Ridge (Figure 4). A node on the Endeavour Segment (Figures 3 and 4) of the Juan de Fuca Ridge will provide power and Ethernet communications to experiments in two of the Endeavour hydrothermal vent fields (Main Endeavour and Mothra; Figure 3). Other nodes on NEPTUNE Stage 1 will support re- 
search in continental shelf, margin, and mid-plate settings.

The multidisciplinary community science experiments at the two Endeavour vent fields will use instruments such as temperature and dissolved gas sensors, fluid samplers, cameras, acoustic scintillometers, and seismometers to study linkages among tectonic, hydrothermal, and biological processes.

Seismic activity is very intensive on the Endeavour Segment and likely to impact the fluid circulation in the crust that leads to hydrothermal venting. Monitoring seismic events together with heat and chemical output from vents will enable detailed study of the influence of seismicity on hydrothermal activity. The impact of hydrothermal discharge on the abundant microbial and specialized faunal communities that colonize the Endeavour vents will also be studied. At high-temperature vents, microbial growth will be monitored in microbial incubators inserted into the walls of hydrothermal chimneys. High-resolution imaging tools will be used at lower-temperature, diffuse-flow vents to monitor the response of microbial mats and the vent faunas to environmental fluctuations. The aggregate thermal and chemical output of the large hydrothermal vent fields of the Endeavour Segment has a detectable influence on oceanographic circulation patterns in the area, and produces a kilometer-scale, deep-water plume rich in microbial cells and dissolved chemicals that attracts concentrations of plankton. The NEPTUNE project provides a first-time opportunity to quantify the total output from a series of vent fields and its regional impact. An array

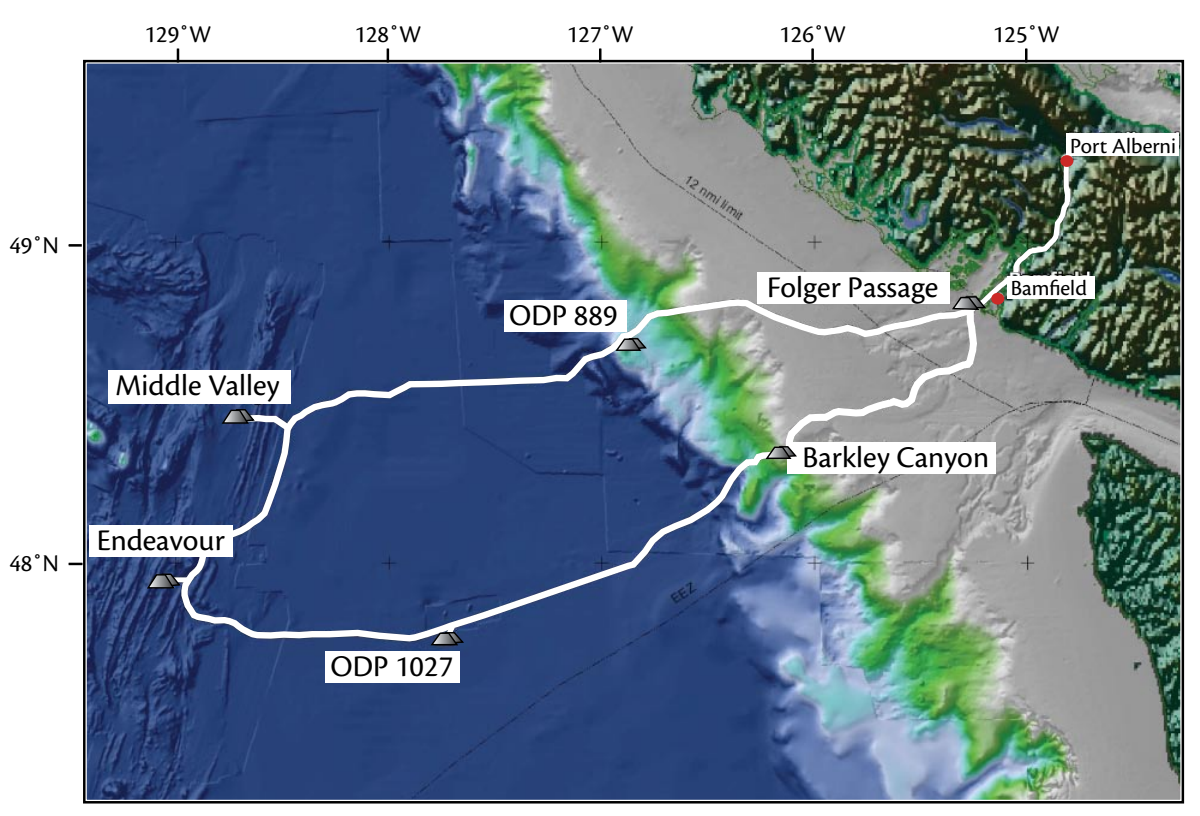

Figure 4. Cable route and seafloor node locations for the NEPTUNE Canada cabled ocean observatory in the Northeast Pacific, off Vancouver Island. Cable, nodes, and first observatory instruments will be deployed in 2008 .

of instrumented moorings positioned along and across the axis of the ridge will permit real-time monitoring of output from the vents and its influence on the physics, chemistry, and biology of the overlying ocean.

The US-based ORION (Ocean Research Interactive Observatory Networks) Project Office, supported through the National Science Foundation's Ocean Observatory Initiative (OOI), is developing Stage 2 of the NEPTUNE RCO. This second stage will place a node on the Juan de Fuca Ridge at Axial Volcano (Figure 3) to take advantage of frequent eruptive and dikeinjection events at this location. Axial Volcano is more volcanically active than other areas of the Juan de Fuca Ridge and has produced several eruptive events over the past two decades.
Integrated Study Sites (ISS)

The Ridge 2000 program has identified three locations for coordinated, wholesystem studies of spreading-center processes. The ultimate goal of the ISS program is to develop whole-system models from the results of integrated, interdisciplinary investigations. Field programs at all ISS will combine surveys, time-series observations, sampling, and in situ experiments designed to elucidate linkages between and among physical, chemical, and biological processes at ridges.

\section{Medium-Spreading Ridges-Endeavour Segment. Underway or planned ISS re- search at Endeavour Segment, Juan de Fuca Ridge, addresses questions at many spatial scales, from segment-scale inves- tigations of structure, seismic activity, hydrology, and petrology to centimeter-}


scale experiments in the walls of black smokers. Some ISS studies will soon make use of the NEPTUNE infrastructure. Others will deploy autonomous instruments. It is anticipated that the presence of the NEPTUNE Canada node at the Endeavour Segment will have a synergistic effect on the development of the ISS. The continuous, real-time monitoring by many instruments will provide an unprecedented wealth of background information for planning and conducting additional experiments, and for interpreting results. Further information and updates on the Endeavour ISS are available on the Ridge 2000 Web site (www.ridge2000.org).

\section{Fast-Spreading Ridges $-8-11^{\circ} \mathrm{N}$, East} Pacific Rise. Fast-spreading ridges with a robust magma supply such as that found on the East Pacific Rise at $8-11^{\circ} \mathrm{N}$ are attractive locations for interdisciplinary studies of the consequences of accretionary events. In such settings there is a high probability of observing a lava intrusion or eruption within a 5-10 year monitoring program. The geological setting of the ISS at $8-11^{\circ} \mathrm{N}$ on the East Pacific Rise is very well documented, as are the abundant hydrothermal vents and their biological communities. Since the 1991 eruptive event at $9^{\circ} 50^{\prime} \mathrm{N}$, the research community has accumulated a wealth of information on the biological and hydrothermal evolution of fast-spreading ridges following a major volcanic perturbation. Knowledge of the setting and dynamics of the $8-11^{\circ} \mathrm{N}$ area is providing opportunities for advanced, integrated studies of process linkages on fast-spreading ridges, and many investigations are presently underway. An intensive 2006-2007 fieldinstrument program is being coordinated that uses autonomous instruments deployed and recovered from ships and submersibles. A recent (April 2006) seafloor eruption in the $8-11^{\circ} \mathrm{N}$ area is greatly enhancing the value of the data return from these deployments. Background information and updates on the $8-11^{\circ} \mathrm{N}$ East Pacific Rise ISS are available on the Ridge 2000 Web site (www. ridge2000.org).

\section{Back-Arc Spreading Ridges-ISS in the} Lau Basin. The inclusion of back-arc spreading centers in observatory studies increases the range of crustal structure, mantle dynamics, and fluid and rock compositions that can be included in investigations, and adds geographic and biological diversity. Compared to midocean ridges, back-arc basins also offer closer compositional and process analogs for terrestrial polymetallic sulfide deposits that are of economic importance. Such is the rationale for the selection of the Lau Basin back-arc spreading center as the third ISS location of the Ridge 2000 program. The geophysical setting of this area is well characterized, as are most other major features of interest to ISS studies, including hydrothermal venting, sulfide mineralization, and the vent biological communities.

One component of the investigative strategy for the Lau Basin ISS builds on a natural feature of the area that permits unusually good visualization of the crust and underlying mantle. High-frequency, local seismicity in the subducting slab underlies and "illuminates" the entire spreading center. This feature will allow seismic studies of mantle flow pat- terns and their relationship to magma production and transport, fluid circulation, and the distribution of subsurface and seafloor biological communities. The heterogeneous geochemistry of hydrothermal fluids in the Lau Basin and its geographical isolation also make the area appealing for biological studies. The remote location of the Lau Basin ISS for research vessels based in northernhemisphere countries presents certain logistical challenges. For this reason, the Lau Basin ISS will require international coordination of scientific effort to accomplish its research objectives. Background information and updates on the Lau Basin ISS are available on the Ridge 2000 Web site (www.ridge2000.org).

\section{CONCLUSION-THE DATA}

\section{CHALLENGE}

Initiatives to monitor and observe midocean ridge processes arise from a growing recognition that solid earth and ocean processes are linked, and those links cannot be understood without a coordinated effort by scientists representing many disciplines and countries. International, interdisciplinary scientific collaborations constructed around specific problems and hypotheses will continue to be the basis for many observatory experiments and will be key elements of the research effort. However, the flow of data from observatory instruments will be such that single investigators and groups of researchers will be unable to process and interpret all incoming information to its full potential, or in many cases, to even a fraction of its full potential.

To accelerate use of data archives generated by observatory research at 
mid-ocean ridges, and thus accelerate the pace of discovery, the challenge to all of these observatory programs will be to develop data-access policies aimed at engaging a larger community in the research effort and creating an new culture of collaboration. These programs will need to reconcile this goal with the interests and intellectual property rights of investigators who conceive experiments, secure funding, and deploy instruments on the seafloor. In developing data-access policies, we must also take into account the very practical issues of the cost and complexity involved in controlling online access to data.

\section{ACKNOWLEDGEMENTS}

The preparation of this article was supported by travel funds to S.K.J. from NSERC Canada Discovery grant \#134794-06 and by NEPTUNE Canada. M.C. and J.E. acknowledge support from the Institut de Physique du Globe. Two anonymous reviewers contributed helpful suggestions for improving this article. Deb Kelley kindly provided the Endeavour segment map in Figure 3.

\section{REFERENCES}

Baker, E.T., German, C.R., and H. Elderfield. 1995b. Hydrothermal plumes over spreading-center axes: Global distributions and geological inferences. Pp. 47-71 in Seafloor Hydrothermal Systems: Physical, Chemical, Biological, and Geological Interactions. S.E Humphris, R.A. Zierenberg, L.S. Mullineaux, and R.E. Thomson, eds, Geophysical Monograph 91, American Geophysical Union, Washington, DC.

Bird, P. 2003. An updated digital model of plate boundaries. Geochemistry, Geophysics Geosystems 4(3): doi:10.1029/2001GC000252.

Bougault, H., J.-L. Charlou, Y. Fouquet, H.D. Needham, N. Vaslet, P. Appriou, P. Jean Baptiste, P.A. Rona, L. Dmitriev, and S. Silantiev. 1993. Fast and slow-spreading ridges: Structure and hydrothermal activity, ultramafic topographic highs, and $\mathrm{CH}_{4}$ output, Journal of Geophysical
Research 98 (B6):9,643-9,651.

Charlou, J.L., J.P. Donval, P. Jean Baptiste, and N.G. Holm. 2002. Geochemistry of high $\mathrm{H}_{2}$ and $\mathrm{CH}_{4}$ vent fluids issuing from ultramafic rocks at the Rainbow hydrothermal field. Chemical Geology 191:345-359.

Dai, A.G., and K.E. Trenberth. 2002. Estimates of freshwater discharge from continents: Latitudinal and seasonal variations. Journal of Hydrometeorology 3:660-687.

Dunn, R.A., D.R. Toomey, and S.C. Solomon. 2000. Three-dimensional seismic structure and physical properties of the crust and shallow mantle beneath the East Pacific Rise at 9 $30^{\prime}$ N. Journal of Geophysical Research 105:23,537-23,555.

Dziak, R.P., D.K. Smith, D.R. Bohnenstiehl, C.G. Fox, D. Desbruyères, H. Matsumoto, M. Tolstoy, and D.J. Fornari. 2004. Evidence of a recent magma dike intrusion at the slow spreading Lucky Strike segment, Mid-Atlantic Ridge. Journal of Geophysical Research 109(B12102), doi:12110.11029/12004JB003141.

Embley, R.W., W.W. Chadwick Jr., D. Clague, and D. Stakes. 1999. 1998 eruption at Axial Volcano: Multibeam anomalies and seafloor observations. Geophysical Research Letters 26:3,4253,428 .

Fox C.G., W.E. Radford, R.P. Dziak, T.-K. Lau, H. Matsumoto, and A.E. Schreiner. 1995. Acoustic detection of a seafloor spreading episode on the Juan de Fuca Ridge using military hydrophone arrays. Geophysical Research Letters 22:131-134.

Fustec, A., D. Desbruyères, and S.K. Juniper. 1987. Deep- sea hydrothermal vent communities at $13^{\circ} \mathrm{N}$ on the East Pacific Rise: Microdistribution and temporal variations. Biological Oceanography 4:121-164.

Gràcia, E., J.L. Charlou, J.R. Radford-Knoery, and L.M. Parson. 2000. Non-transform offsets along the Mid-Atlantic Ridge south of the Azores $\left(38^{\circ} \mathrm{N} 34^{\circ} \mathrm{N}\right)$ : Ultramafic exposures and hosting of hydrothermal vents. Earth and Planetary Science Letters 177:89-103.

Haymon, R.M., D.J. Fornari, K.L. Von Damm, M.D. Lilley, M.R. Perfit, J.M. Edmond, W.C Shanks III, R.A. Lutz, J.M. Grebmeier, S. Carbotte, D. Wright, E. McLaughlin, M. Smith, N. Beedle, and E. Olson. 1993. Volcanic eruption of the mid-ocean ridge along the East Pacific Rise crest at $9^{\circ} 45-52^{\prime} \mathrm{N}$ : Direct submersible observations of sea floor phenomena associated with an eruption event in April, 1991. Earth and Planetary Science Letters 119:85-101.

Heirtzler, J.R., and X. Le Pichon. 1974. FAMOUS: A plate tectonics study of the genesis of the lithosphere. Geology 2:273-274.

Hessler, R.R., W.M. Smithey, M.A. Boudrias, C.H. Keller, R.A. Lutz, and J.J. Childress. 1988. Temporal change in megafauna at the Rose Garden hydrothermal vent (Galápagos Rift; eastern tropical Pacific). Deep-Sea Research
35:1,681-1,709.

Holm, N.G., and J.L. Charlou. 2001. Initial indications of abiotic formation of hydrocarbons in the Rainbow ultramafic hydrothermal system, Mid-Atlantic Ridge. Earth and Planetary Science Letters 19:1-8.

Huber, J.A., D.A. Butterfield, and J.A. Baross. 2003. Bacterial diversity in a subseafloor habitat following a deep-sea volcanic eruption. FEMS Microbial Ecology 43:393-409.

Johnson, H.P., M. Hutnak, R.P. Dziak, C.G. Fox, I. Urcuyo, J.P. Cowen, J. Nabelek, and C.R. Fisher. 2000. Earthquake-induced changes in a hydrothermal system at the Endeavour Segment, Juan de Fuca Ridge. Nature 407:174-177.

Juniper S.K., P. Martineu, J. Sarrazin, and Y. Gelinas. 1995. Microbial mineral floc associated with nascent hydrothermal activity on CoAxial segment, Juan de Fuca Ridge. Geophysical Research Letters 22:179-182.

Kristall, B., D.S. Kelley, M.D. Hannington, and J.R. Delaney. 2006. Growth history of a diffusely venting sulfide structure from the Juan de Fuca Ridge: A petrological and geochemical study. G3: Geochemistry Geophysics Geosystems 7, Q07001, doi:10.1029/2005GC001166.

Lonsdale, P. 1977. Clustering of suspension-feeding macrobenthos near abyssal hydrothermal vents at oceanic spreading centers. Deep-Sea Research 24:857-863.

Sarrazin, J., V. Robigou, S.K. Juniper, and J.R. Delaney. 1997. Biological and geological dynamics over four years on a high-temperature sulfide structure at the Juan de Fuca Ridge hydrothermal observatory. Marine Ecology Progress Series 153:5-24.

Shank, T.M., D.J. Fornari, K.L. Von Damm, M.D. Lilley, R.M. Haymon, and R.A. Lutz. 1998. Temporal and spatial patterns of biological community development at nascent deep-sea hydrothermal vents along the East Pacific Rise. Deep-Sea Research 45:465-515.

Singh, S., W. Crawford, H. Carton, T. Seher, V. Combier, M. Cannat, J.P. Canales, D. Dusunur, J. Escartín, and J.M. Miranda. 2006. Discovery of axial magma chamber reflection and faults beneath the Lucky Strike volcano and hydrothermal vents at the Mid-Atlantic Ridge. Nature 442:1,029-1,032.

Stein, C.A., and S. Stein. 1994. Constraints on hydrothermal heat flux through the oceanic lithosphere from global heat flow. Journal of Geophysical Research 99:3,081-3,095.

Tunnicliffe, V., R.W. Embley, J.F. Holden, D.A. Butterfield, G. Massoth, and S.K. Juniper. 1997. Biological colonization of new hydrothermal vents following an eruption on Juan de Fuca Ridge. Deep-Sea Research 44:1,627-1,644 